\title{
Human T-Cell Lymphotropic Viruses Type 1 and 2 (HTLV-I/-II)
}

\author{
Arbeitskreis Blut, Untergruppe «Bewertung Blutassoziierter Krankheitserreger»
}

\section{Present State of Knowledge on the Virus}

\subsection{Characteristics of HTLV-I/-II}

The family of the retroviruses is divided into seven groups [1]. The human T-cell leukaemia viruses type 1 and type 2 (HTLVI/-II), together with the bovine leukaemia virus (BLV) and the simian T-cell leukaemia viruses (STLV), form the group HTLV-BLV. The retrovirus genome consists of a linear single-stranded RNA (vRNA) 7,200-10,000 bases in length. There are two identical copies in each virus particle. The vRNA is surrounded by the nucleocapsid protein and enclosed by the core (CA). Inside the retrovirus particle there are three virus-encoded enzyme activities: viral protease, reverse transcriptase and integrase. The lipid envelope of the retrovirus is formed during the process of budding through the cell membrane (maturation). The transmembrane protein serves as an anchor for the surface protein. Beneath the lipid membrane is the matrix protein.

The genome of replication-competent retroviruses encodes three genes: gag for the internal structural proteins (groupspecific antigens), env for the envelope proteins and pol (polymerase) for the viral enzymes. Each of these genes encodes a precursor protein which is processed post-transcriptionally into the respective functional protein. The precursors for the Gag and Pol proteins are cleaved enzymatically into the end products by the viral protease, the glycoprotein precursor by a cellular protease of the furin protease type.

Adsorption of the virions takes place via specific cell membrane receptors with the help of the surface glycoprotein and is followed by their entry into the cell (penetration). The reverse transcriptase transcribes the viral RNA into doublestranded DNA which, as so-called provirus (proviral DNA), is integrated covalently into the host cell genome with the help of the integrase. To the right and left of the coding sequences the genome is flanked by LTR (long terminal repeats) sequences which contain the cis-acting regulatory elements for efficient regulation of virus replication.

After infection, proviruses can remain integrated in the cells for a long time without synthesis of viral components taking
Table 1. Proteins of the human T-cell lymphotropic viruses

$$
\text { HTLV-I HTLV-II Function }
$$

gag-encoded proteins

$\begin{array}{lll}\text { p53 } & \text { p53 } & \text { precursor protein } \\ \text { p24 } & \text { p24 } & \text { capsid antigen } \\ \text { p19 } & \text { p19 } & \text { matrix antigen } \\ \text { p15 } & \text { p15 } & \text { nucleocapsid protein ? }\end{array}$

pol-encoded proteins

$\begin{array}{lll}\text { p14 } & \text { p14 } & \text { protease } \\ \text { p95 } & \text { p95 } & \text { polymerase (precursor?) } \\ (\text { p62 }) & (\text { p62 }) & \text { reverse transcriptase } \\ (\text { p32 }) & (\text { p32 }) & \text { (integrase) }\end{array}$

$e n v$-encoded proteins

$\begin{array}{lll}\text { gp61-68 } & \text { gp61-68 } & \text { precursor protein } \\ \text { gp46 } & \text { gp46 } & \text { surface glycoprotein } \\ \text { gp21 } & \text { gp21 } & \text { transmembrane protein }\end{array}$

Regulatory proteins (non-structural proteins)

\begin{tabular}{lll}
\hline p40 & p37 & Tax (transactivator (LTR)) \\
p21/p27 & p24/p26 & $\begin{array}{l}\text { Rex (mRNA transport, post-transcriptional } \\
\text { regulation) }\end{array}$ \\
& & \\
\hline
\end{tabular}

place. After activation of the cells, synthesis of viral components and thus replication of HTLV is induced. The proviral DNA genome is transcribed into mRNA and vRNA by cellular enzymes (DNA-dependent RNA polymerases). The mRNA serves as a template for the synthesis of the virus structural proteins and enzymes and for the virus regulatory proteins. Specific mRNAs produced by splicing the viral mRNA are used for synthesis of the various virus proteins, unspliced mRNA is used for synthesis of the gag and gag-pol precursor proteins and as genomic RNA.

Assembly of the HTLV particle takes place simultaneously with its release from the cell. The core envelope is formed be-

\begin{tabular}{ll}
\hline KARGER & ๑ 1999 S. Karger GmbH, Freiburg \\
Fax +4976145207 14 & Accessible online at: \\
$\begin{array}{l}\text { E-mail Information@Karger.de } \\
\text { www.karger.com }\end{array}$ & www.karger.com/journals/iut
\end{tabular}


neath the budding structure. Maturation of the virus particle takes place after incorporation of the RNA and budding through the membrane. The spherical core envelope is transformed into a polygonal core which usually lies centrally within the particle. In cell culture pleomorphic virus particles with diameters of 100-180 nm are found. HTLV which is propagated in cell culture is not infectious; infection of new cells only takes place through co-cultivation of infected and non-infected susceptible cells.

Retroviruses usually have a very narrow host range. Only a few examples are known in which species barriers are crossed; this is usually only achieved experimentally. The viruses in the HTLV-BLV group have transforming properties. The Tax protein is involved in the induction and maintenance of transformation. The mechanism of cell transformation by this virus group is different from that of the acutely transforming viruses of the type $\mathrm{B}$ and type $\mathrm{C}$ retrovirus groups.

The replication of HTLV is regulated by the two virus regulatory proteins Tax and Rex. Tax acts as an activator of transcription and is necessary for efficient transcription of the virus genome. Rex is required as a post-transcriptional regulator for up-regulation of the virus structural proteins Gag and Env. At the same time, however, the synthesis of Tax and Rex is suppressed.

The Tax protein also activates cellular genes which play an important role in regulating proliferation and differentiation of the cells. For example, it induces IL-2 and the IL-2 receptor, and leads to increased production of GM-CSF.

\subsection{Infection and Infectious Diseases}

Three HTLV-I-associated diseases have been described to date: adult T-cell leukaemia (ATL) [2, 3], tropical spastic paraparesis (TSP) or HTLV-associated myelopathy (HAM) [4, 5], and more recently HTLV-I-associated arthropathy [6]. ATL was first associated with HTLV-I infection in the years 1979/80, TSP/HAM in 1985 and HTLV-I-associated arthropathy in 1989. HTLV-I-associated arthropathy was first described in areas of endemic HTLV-I in Japan.

It is not yet clear which co-factors are involved in the clinical manifestation of HTLV infection in persons infected with the virus. The epidemiological data indicate that ATL breaks out in individuals who were infected prenatally or postnatally through breast feeding. The incubation period is very long and can be 40 years or more. The manifestation rate is about 1-5\% [7]. ATL manifests as aggressive T-cell leukaemia (lymphoma) with monoclonal growth of CD4-positive T cells. Hypercalcaemia, lytic bone marrow lesions, skin infiltration and eosinophilia are frequently observed. In addition, B-cell lymphomas are described which may be promoted by the simultaneously occurring immunosuppression. The discovery, shortly after its first description, that HTLV can produce immunosuppression in infected persons implicated HTLV-I as a candidate for the AIDS pathogen before HIV-1 was identified as the AIDS-causing virus.
In patients with TSP/HAM poly- or oligoclonal expansion of $\mathrm{T}$ cells is found. TSP/HAM occurs in individuals who were infected as newborns or after puberty, usually through sexual contact. The incubation period appears to be shorter than for ATL. In transfusion-associated TSP the incubation period can be as short as a few months. The manifestation rate of TSP/HAM appears to vary, with rates of up to $10 \%$ reported in some endemic areas. The clinical onset of HTLV-I-associated TSP/HAM is insidious. The slow, progressive development of the disease often affects only the lower extremities to begin with. The first symptoms are incontinence and increasing difficulties walking as well as weakness and stiffness, usually of both legs. The further course is chronic and, in contrast to multiple sclerosis (MS), a relapsing-remitting course is not observed. So far, the suspicion that HTLV-I or a related virus is involved in the development of MS has not been corroborated.

In HTLV-I-endemic areas the seroprevalence is higher in women than in men (ratio about 2:1). The ratio is the same for patients with clinical symptoms.

In the majority of cases HTLV-II infection has no pathogenicity. HTLV-II, first isolated from a patient with hairy-cell leukaemia [8], could not initially be linked to specific diseases. HTLV-II transmission by blood transfusions led to TSP-like symptoms [9]. Recent findings suggest that various diseases can occur in HTLV-II infected individuals, including TSP/HAM-like diseases, ataxia, incontinence, eczematous erythema, hairy-cell leukaemia (granulocytic leukaemia); that is, the spectrum of HTLV-II-associated diseases is growing and includes leukaemias, neurological and pulmonary diseases $[9,10]$.

Transmission of HTLV-I/-II appears to be strictly cell associated. HTLV-I can be transmitted in utero or, apparently far more often, through breast feeding [11]. Transmission by sexual intercourse is more common from an HTLV-I-infected man to a non-infected partner than from an infected woman to her partner [12]. Epidemiological studies indicate that transmission of HTLV-I is always cell associated [13]. A decrease in the risk of infection by whole blood is observed after storage $[14,15]$. If freshly collected blood is transfused, the risk of transmission of infection is about $60 \%$ [16].

Investigations amongst drug users in the USA and Italy show that the efficiency of transmission through shared needles appears to be high. The equal sex distribution of HTLV-II seropositivity amongst American Indians suggests that HTLV-II may be transmitted more efficiently from an infected woman to her partner than HTLV-I [17].

Both HTLV-I and HTLV-II infection is observed in intravenous drug users (IVDU). The prevalences can vary considerably. Thus, in the USA prevalences of between $0.4 \%$ and $18 \%$ were found in different cities. In other European countries where HTLV is not endemic, for example Italy, the majority of HTLV-II infections were found in the IVDU population [18]. 


\subsection{Epidemiology}

HTLV-I is endemic in Japan, the Caribbean and Africa [19]. The occurrence of HTLV-I infection in other regions (USA, South America, Iran, Australia, New Guinea, Melanesia) has also been reported [20-22]. In the USA, HTLV-II infection was first seen only sporadically [8] and amongst IVDU [23]. More recent investigations indicate that HTLV-II is endemic amongst North and South American Indian tribes and in pygmy tribes of Central Africa, with prevalences of up to $70 \%$ in some regions $[17,24]$.

In Europe cases of HTLV-I infection have been observed in countries which have close traditional ties to endemic areas, such as UK, France, The Netherlands and Portugal [25, 26]. Cases of HTLV-II infection have so far usually been confined to the IVDU population, particularly in Italy, Sweden and Spain.

In contrast to other European countries, Germany has no traditional ties to endemic areas, therefore unlike France, UK, Portugal and The Netherlands, there are relatively few migrants from endemic areas living in this country. The expected and so far observed numbers of cases of HTLV infection and disease are therefore correspondingly low [27, 28]. The cases of HTLV-associated disease so far reported in Germany were either in migrants from endemic areas or in individuals who had travelled from endemic areas to Germany for treatment [29-31]. Only one person with TSP symptoms was of German origin but reported frequent travel to endemic areas $(\mathrm{H}$. Schmitz, personal communication). The first German case of ATL was described in 1996 [32]. Further evidently imported cases have recently occurred in Heidelberg (patient from South America), Tübingen (patient from Japan), the Saarland (patient from West Africa) and Berlin (patients from West Africa and China). Investigations in blood donors are discussed in section 2.1.

Studies of sera of neonates showed the following results for 1996: Of about 30,000 samples tested by the Robert Koch-Institut (RKI) in Berlin for HTLV antibodies as well as HIV antibodies in the context of the study 'Anonymous Unlinked Testing (AUT)' two were positive for HTLV antibodies. Of 1,600 samples tested at the Max-von-Pettenkofer-Institut in Munich one HTLV-I antibody-positive sample was found (K. von der Helm, personal communication).

\subsection{Detection Methods and Their Significance}

HTLV-I and -II are closely related. Antibody screening tests developed for HTLV-I also recognise sera containing antibodies against HTLV-II in a high percentage of cases. In Germany HTLV-I/-II tests do not currently have to be licensed by the Paul-Ehrlich-Institut (Federal Office for Sera and Vaccines). As in the case of HIV-1 and -2, the commercially available HTLV-I antibody screening tests are based on a number of different test principles, e.g. particle agglutination and ELISA (enzyme linked immunosorbent assays) tests. As tests of this type can also produce false-positive results, the results must be confirmed by other methods.
Particle agglutination tests are used particularly in Japan for testing blood donations and for epidemiological studies. The test is simple to perform and the result is available in about $2 \mathrm{~h}$.

ELISA tests are available from various manufacturers. The majority of the tests on the market use whole virus antigen. The viruses are grown on different lymphoid cells, which can influence the sensitivity and specificity of the various tests. In addition, antibody tests using synthetic peptides have also been developed. As HTLV-II is evidently of greater clinical significance than hitherto assumed, combined HTLV-I/-II tests have been developed.

Confirmatory Tests. The immunofluorescence test is suitable for confirmation of samples which test positive in antibody screening tests. However, the tests should only be evaluated by experienced investigators. HTLV-infected culture cells are used, non-infected cells are used as a control. This test can be used for differentiation between HTLV-I and -II infections. However, as the two viruses are closely related, differentiation is only possible by determination of the respective antibody titres.

In recent years the Western blots (immunoblots) for HTLV-I/-II have been improved. The Western blot strips are coated on the one hand with virus antigens (HTLV-I) obtained by purification of virus from culture supernatant. On the other hand recombinant proteins are also applied. Recombinant transmembrane protein gp21 (rgp21, improved version: GD21) and typespecific sequences of the outer envelope glycoprotein gp46 (rgp46-I and rgp 46-II) are used. These type-specific antigens permit differentiation between HTLV-I and -II antibodies.

The radioimmunoprecipitation assay can only be performed in specialised laboratories. For performance of the assay HTLVI-infected cells are cultured in the presence of radiolabelled amino acids. After lysis of the cells the antibodies are allowed to react with the HTLV antigen and the antigen-antibody complexes are separated on SDS polyacrylamide gels. The radiolabelled antigens are then detected by autoradiography. This test is usually only used for further clarification of samples which produce indeterminate results in the Western blot. Detection of antibodies against viral precursor glycoprotein gp68 is proof of HTLV-I infection.

In cases which cannot be definitively diagnosed by serological testing the polymerase chain reaction (PCR) is used for final clarification of the status of infection. In addition, the use of different primer pairs and hybridisation probes permits differentiation between HTLV-I and -II.

In the context of the collaboration between different laboratories in Europe the following test strategy for the serological detection of HTLV infection has been proposed: Examination of the samples in an antibody screening test, examination of repeatedly reactive samples with a further screening test, sera which are again reactive are tested by Western blot. Western blot tests which contain the recombinant proteins rgp21 (GD21), rgp46-I and rgp46-II in addition to the HTLV pro- 
teins should be used. Sera are regarded as HTLV-I positive if they react with Gag proteins (p19 and/or p24), rgp21 (GD21) and rgp46-I and as HTLV-II positive if they react with Gag (p19 and/or p24), rgp21 (GD21) and rgp46-II. In isolated cases sera have been found which only react with the recombinant transmembrane protein gp21 (GD21) and internal proteins. In these cases the infection status must be clarified with the PCR. Sera which are non-reactive in the antibody screening tests or which are reactive in the screening test but non-reactive in the Western blot are HTLV-I/-II negative. All sera which recognise one or more HTLV antigens in the Western blot are classed as HTLV-I/-II indeterminate. Subjects with the latter reaction pattern should be examined in further tests if appropriate.

Problems of Serological Testing in Germany. In low-prevalence countries or regions such as Germany serological diagnosis is problematic. Sera which are reactive in several antibody screening tests are often also reactive in the Western blot. Here mainly reactions with the internal proteins p24 and p19 and the Gag precursor proteins are observed. Reactions with the recombinant gp21 (rgp21, GD21) transmembrane protein are less common. It is not clear whether the observed reactions with HTLV antigen are non-specific or due to crossreactions with antigen of HTLV-related viruses. To determine this, we need further virological and molecular biological studies which must include not only high-risk persons (persons from endemic areas, IVDU) but also patients with diseases which indicate HTLV-I/-II infection. Patients with neurological, haematological and dermatological symptoms in whom other causes have been ruled out should therefore be tested for possible HTLV infection. According to recent data, patients with rheumatoid, pulmonary and possibly autoimmune diseases can be included for the differential diagnosis. In the majority of the sera which can be classed as HTLV positive according to the criteria of the Centers for Disease Control (USA) (reaction with one internal and one envelope protein) differentiation between HTLV-I and HTLV-II was not possible as the sera only reacted with the recombinant transmembrane protein GD21 and not with the type-specific glycoprotein gp46. This group must be further examined by PCR or virus culture as it is not clear whether these reactions are really due to HTLV-I or -II infection or whether other as yet undiscovered pathogens are responsible for the reactivity in the various tests.

\section{Blood and Plasma Donors}

\subsection{Prevalence and Incidence in Donor Populations}

In Japan (1986), the USA (1989/90), France (1991), The Netherlands (1993), Luxembourg (1994), Denmark (1994), Sweden (1994) and Finland (1995) all blood donors are tested for HTLV-I antibodies. The prevalences vary between 0 and
$0.02 \%$ [33]. In Germany results are currently available from the following studies: The Bavarian Red Cross (BRK) in collaboration with the RKI identified $4 \mathrm{HTLV}-\mathrm{I} /$-II positive donors $(2 \times$ HTLV-I, $2 \times$ HTLV-II $)$ amongst approximately 376,000 donors in the years 1991-1994 [34]. The Max-von-Pettenkofer-Institut, Munich, described 2 HTLV-I infections amongst approximately 76,000 donors in 1994.

The Blood Donor Service of the University Hospital Hamburg-Eppendorf found 1 HTLV-I infection amongst 9,700 donors (RKI confirmation with Western blot and PCR) and the Blood Donor Service of the University of Mainz described 1 HTLV-II infection amongst 11,000 donors [35]. In a joint study by the German Red Cross (DRK) in Hessen, the Blood Donor Service in Frankfurt/M. and the Paul-EhrlichInstitut (1996/1997) there were no samples confirmed positive for HTLV-I/-II antibodies amongst 100,825 donors.

On account of the small number of HTLV-positive donors it is not possible to give a precise prevalence. The figure can be assumed to lie somewhere between 1 in 10,000 and 1 in 100,000. No statement on the incidence can be made.

\subsection{Donor Testing and Significance}

Improvements in the antibody screening tests have reduced the previously observed rate of $0.3-0.4 \%$ reactive sera by about the factor 10 without giving rise to sensitivity or specificity problems. In the confirmations performed by the RKI the rate of not definitely confirmable sera was between $97 \%$ ( 1 of about 30 sera repeatedly reactive in the first ELISA) and $99 \%$. Sera which were reactive in at least two antibody screening tests were usually also reactive in the Western blot without the majority of the reactive donations being confirmed. Investigations by the Dutch Red Cross assume that $75 \%$ of the repeatedly reactive sera are not confirmed. In principle all persons with an indeterminate result in the Western blot must undergo further testing by PCR [37].

\subsection{Donor Interviews}

In principle it is possible to ask donors whether they or their sexual partners come from endemic areas (see 1.3; routes of transmission see 1.2). However, the practicability of such a procedure is questionable.

\subsection{Donor Information and Counselling}

Donors must be informed that infection with HTLV-I/-II carries only a small risk of developing HTLV-associated disease. The main routes of transmission are sexual intercourse or mother-to-child (primarily through breast feeding but also in utero); transmission can therefore be prevented by taking appropriate measures.

Problems arise if indeterminate results are obtained in the antibody screening tests and the confirmatory tests. Information of donors only appears necessary in cases of definitely confirmed results (unambiguous confirmatory test and/or PCR). 


\section{Recipients}

\subsection{Prevalence and Incidence of Blood-Associated}

Infections and Infectious Diseases in Recipient Populations

No cases of transmission of HTLV infection through blood or blood products have been reported in Germany to date. In the case of the Mainz donation no infection was detected in the recipients.

\subsection{Immune Status (Resistance, Existing Immunity,}

Immune Response, Age, Exogenous Factors)

No genetic or immunological resistance has been reported to date (see also 1.2).

\subsection{Severity and Course of the Disease}

No cases of primary disease are known. After infection through a blood transfusion TSP-like symptoms can develop within a few months. No cases of ATL following transfusion have been observed to date, possibly on account of the long incubation period.

\subsection{Therapy and Prophylaxis}

The possibilities of treatment are limited. TSP has a chronic course. It is not possible to say with certainty at present to what extent nucleoside analogues and interferon therapy are able to delay progression of the disease. Cure does not appear possible at present on account of the properties of the virus (retrovirus). There is no immunisation.

\subsection{Transmissibility}

HTLV-I/-II can be transmitted by sexual intercourse. Transmission from mother to child can take place in utero $(2-5 \%)$ or with the breast milk during breast feeding (depending on the duration of breast feeding up to $25 \%$ ). Bottle feeding considerably decreases the probability of postnatal infection; HTLV-I/-II carriers should therefore not breast feed.

\subsection{Frequency of Administration, Type and Amount of Blood Products}

So far only one case of transmission of HTLV-I/-II through cellular blood products has been observed. Retrospective studies indicate that there is a variable risk of transmission through cellular blood products (red cell concentrate, platelet concentrate, whole blood). There is a higher risk for patients receiving donations which have been stored for less than 5 days $[14,15]$.

\section{Blood Products}

4.1 Infectious Load of the Starting Material and Test Methods So far transmission has only been observed through cellular products. Infection with HTLV-I/-II can be detected by antibody testing.

\subsection{Methods for Removal and Inactivation of the Infectious Agent} Infectious virus is cell bound (mainly CD4-positive cells are infected). Removal of the leucocytes may reduce the risk of infection through blood products. No cases of transmission through factor preparations or other cell-free products have been reported to date.

\subsection{Feasibility and Validation of Procedures for Removal/Inactivation of the Infectious Agent}

Transmission of HTLV-I/-II is cell associated. The extent to which leucocyte depletion eliminates infected cells has not yet been investigated.

\section{Assessment}

In consideration of the fact that HTLV is only transmitted by cellular blood products and that the infectivity of the products decreases during storage, the overall risk of infection is low; however, transmission cannot be entirely ruled out. As we lack data on transmission of HTLV-I/-II through transfusions, it is recommended that patients with (HTLV-associated) central nervous symptoms should be asked specifically about previous transfusions.

The investigations performed in Germany and Europe show that most countries have a low prevalence of HTLV-I/-II infection. In confirmed positive donors there was usually a direct connection with the origin of the donor or his/her partner from an endemic area. So far no cases of seroconversion have been observed in the European blood donor population.

In order to reduce the risk of infection through blood products, it is recommended that blood donors who, in accordance with the 'Guidelines for Blood Grouping and Blood Transfusion (Haemotherapy)', were temporarily deferred because of an association (e.g. origin, travel, sexual partner) with areas endemic for relevant pathogens should be tested for HTLV-I/II antibodies before resuming donation. In the context of the forthcoming revision, the 'Guidelines for Blood Grouping and Blood Transfusion (Haemotherapy)' should be checked to ensure that the endemic areas for HTLV-I/-II are covered. Another possibility of practically avoiding the risk of infection with HTLV-I/-II is leucocyte depletion of the labile blood products. This could also make testing for HTLV-I/-II antibodies superfluous.

This article was drawn up by the sub-group 'Evaluation of Blood-Associated Pathogens' of the German Advisory Group 'Blood' (Arbeitskreis Blut) with the participation of:

Prof. Dr. Reinhard Burger, Prof. Dr. Wolfram Gerlich,

Prof. Dr. Lutz Gürtler, Dr. Margarethe Heiden,

Prof. Dr. Volker Kretschmer, Dr. Hans Lefèvre,

PD Dr. Johannes Löwer, Dr. Thomas Montag-Lessing,

PD Dr. Rainer Neumann, Prof. Dr. Georg Pauli,

Prof. Dr. Rainer Seitz, Dipl.-Med. Uwe Schlenkrich,

Dr. Edgar Werner, Dr. Hannelore Willkommen

The paper was passed by the German Advisory Group (Arbeitskreis Blut) on July 14, 1998. 


\section{References}

1 Murphy FA, Fauquet CM, Bishop DHL, Ghabrial SA, Jarvis AW, Martelli GP., Mayo MA, Summers, MD: Virus Taxonomy: Classification and Nomenclature of Viruses. Wien, Springer, 1995.

2 Poiesz BJ, RuscettiFW, Gazdar AF, Bunn PA, Minna JD, Gallo RC: Detection and isolation of type C retrovirus particles from fresh and cultured lymphocytes of a patient with cutaneous T-cell lymphoma. Proc Natl Acad Sci USA 1980;77:74157419.

3 Miyoshi I, Kubonishi L, Yoshimoto S, Akagi T, Otsuki Y, Shiraishi Y, Nagata K, Hinuma Y: Type C virus particles in a cord T-cell line derived by cocultivating normal human cord leukocytes and human leukemic T-cells. Nature 1981;294:770-771.

4 Gessain A, Barin F, Vernant JC, Gout O, Maurs L, Calendar A, de Thé G: Antibodies to human Tlymphotropic virus type-1 in patients with tropical spastic paraparesis. Lancet 1985;ii:407-409.

5 Osame M, Usuku K, Izumo S, Ijichi N, Amitani H, Igata A, Matsumoto M, Tara M: HTLV-1 associated myelopathy, a new clinical entity. Lancet 1986;i: 1031-1032.

6 Iwakura Y, Tosu M, Yoshida E, Takiguchi M, Sato K, Kitajima I, Nishioka K, Yamamoto K, Takeda T, Hanaka M, Yamamoto K, Sekiguchi T: Induction of inflammatory arthropathy resembling rheumatoid arthritis in mice transgenic for HTLV-1. Science 1991;253:1026-1028.

7 Murphy EL, Goedert JJ, Blattner WA, Gibbs WN, Campbell M: Modelling the risk of adult T-cell leukemia/lymphoma in persons infected with human T-lmphotropic virus type I. Int J Cancer 1989; 43:250-253.

8 Kalyanaraman VS, Sarngadharan MG, RobertGuroff M, Miyoshi I, Blayncy D, Golde D, Gallo RC: A new subtype of human T-cell leukemia virus (HTLV-2) associated with a T-cell variant of hairy cell leukemia. Science 1982;218:571-573.

9 Murphy EL: HTLV-2 related disease. Lancet 1993; 341:888.

10 Hjelle B, Appenzeller O, Mills R, Alexander S, Torrez-Martinez N, Jahnke R, Ross G: Chronic neurodegenerative disease associated with HTLVII infection. Lancet 1992;339:645.

11 Sugiyama H, Doi H, Yamaguchi K, Tsuji Y, Miyamoto T, Hino S: Significance of postnatal mother-to-child transmission of human T-lymphotropic virus type-I on the development of adult T-cell leukemia/lymphoma. J Med Virol 1986;20: 253-260.

12 Yamaguchi K: Human T-lymphotropic virus type I in Japan. Lancet 1994;343:213-216.

13 Yamamoto N, Okada M, Koyanagi Y: Transformation of human leukocytes by cocultivation with an adult $\mathrm{T}$ cell leukemia virus producer cell line. Science 1982;217:737-739.
14 Manns A, Wilks RJ, Murphy EL, Haynes G, Figuora JP, Barnett M, Hanchard B, Blattner WA: A prospective study of transmission by transfusion of HTLV-I and risk factors associated with seroconversion. Int J Cancer 1992;51:886-891.

15 Sullivan MT, Williams AE, Fang CT, Grandinetti T, Poiesz BJ, Ehrlich GD, and The American Red Cross HTLV-I/-II Collaborative Group: Transmission of human T-lymphotropic virus type I and II by blood transfusion. A retrospective study of recipients of blood components (1983 through 1988). Arch Int Med 1991;151:2043-2048.

16 Manns A, Murphy EL, Wilks R, Haynes G, Figueroa JP, Hanchard B, Barnett M, Drummond J, Waters D, Cerney M, Seals JR, Alexander SS, Lee H, Blattner WA: Detection of early human T-cell lymphotropic virus type 1 antibody patterns during seroconversion among transfusion recipients. Blood 1991;77:896-905.

17 Levine PH, Jacobson S, Elliott R, Cavallero A Colclough G, Dorry C, Stephenson C, Knigge RM, Drummond J, Nishimura M, Taylor ME, Wiktor S, Shaw GM: HTLV-II Infection in Florida Indians. AIDS Res Hum Retroviruses 1993;9:123-127.

18 Zanetti AR, Zehender G, Tanzi E, Galli C, Rezza G, Cargnel A, Boschini A, Mari D, Pizzocolo G, Mazzota F, Canavaggio M, Lee H: HTLV-II among Italian intravenous drug users and hemophiliacs. Eur J Epidemiol 1992;8:702-707.

19 Höllsberg P, Hafler DA: Pathogenesis of diseases induced by human lymphotropic virus type I infection. Seminars in medicine of the Beth Israel Hospital, Boston. N Engl J Med 1993;328:1173-1182.

20 Bastian I, Gardner J, Webb D, Gardner I: Isolation of a human T-lymphotropic virus type I strain from Australian Aboriginals. J Virol 1993;67:843-851.

21 Gessain A, Boeri E, Yanagihara R, Gallo R, Franchini G: Complete nucleotide sequence of a highly divergent human T-cell leukemia (lymphotropic) virus type I (HTLV-I) variant from Melanesia: Genetic and phylogenetic relationship to HTLV-I strains from other geographical regions. J Virol 1993;67:1015-1023.

22 Blattner WA, Kalyanaraman VS, Robert-Guroff M, Lister TA, Galton DA, Sarin PS, Crawford MH, Catovsky D, Greaves M, Gallo RC: The human type-C retrovirus, HTLV, in the blacks from the Caribbean region and relationship to adult T-cell leukemia/lymphoma. Int J Cancer 1982;30:257264

23 Kwok S, Gallo D, Hanson C, McKinney N, Poiesz B, Sninsky JJ: High prevalence of HTLV-II among intravenous drug abusers: PCR confirmation and typing. AIDS Res Hum Retroviruses 1990;6:561565 .

24 Maloney EM, Biggar RJ, Neel JV, Taylor ME, Hanh BH, Shaw GM, Blattner WA: Endemic human $\mathrm{T}$ cell lymphotropic virus type 2 infection among isolated Brazilian Amerindians. J Inf Dis 1992;166:100-107.
25 Coste J, Lemaire JM, Courouce AM: HTLV-I/II antibodies in French blood donors. Lancet 1990; 335:1167-1168.

26 Mowbray J, Mawson S, Chawira A, Skidmore S, Boxall E, Desselberger U, Nightingale S: Epidemiology of T-cell leukemia/lymphoma virus type 1 (HTLV-1) infections in a subpopulation of AfroCaribbean origin in England. J Med Virol 1989;29: 289-295.

27 Hunsmann G, Schneider J, Bayer H, Berthold H, Schimpf K, Kabisch H, Ritter K, Bienzle H, Schmitz H, Kern P, Dietrich M: Antibodies to adult T-cell leukemia virus (ATLV/HTLV-I) in AIDS patients and people at risk of AIDS in Germany. Med Microbiol Immunol 1985;173:241-250.

28 Pauli G, Ehm I, Gelderblom HR, Koch MA HTLV-1-Infektionen in der Bundesrepublik Deutschland. Bundesgesundheitsblatt 1990;33:205-209.

29 Detmar M, Pauli G, Anagnostopoulos I, Wunderlich U, Herbst H, Garbe C, Stein H, Orfanos CE: A case of classical mycosis fungoides associated with human T-cell lymphotropic virus type 1 . Br J Dermatol 1991;124:198-202.

30 Rolfs A, Junghan U, Pauli G, Koenecke C, Grützedieck V: Neurologisches Krankheitsbild und Diagnostik einer HTLV-1 Infektion mit Paraparese, Myositis und Sjögren-Syndrom. 2. Deutscher AIDS-Kongress, Berlin, 23./24.1.1989, Abstract 312 .

31 Kitze B, Turner RW, Burchhardt M, Poser S, Hunsmann G, Weber T: Differential diagnosis of HTLV-I-associated myelopathy and multiple sclerosis in Iranian patients. Clin Invest 1992;70:10131018.

32 Reinhardt P, Maschmeyer G, Carstanjen D, Schulze G, Herrmann F, Fleischer C, Ellerbrok H, Schlegelberger B, Pauli G, Ludwig WD: Erste nicht-importierte HTLV-I positive adulte T-ZellLeukämie (ATL) in Deutschland. Jahrestag Gesellsch Virol, 6.-9.3.1996, Jena, Abstract 254.

33 HTLV European Research Network (HERN), Taylor GP, Weber JN, et al: Sero-epidemiology of the human T-cell leukaemia/lymphoma viruses in Europe. J Acquir Immune Defic Syndr Hum Retrovirol 1996;13:68-77.

34 Fleischer C, Kücherer C, Michel P, Wiese W, StahlHennig C, Bodemer C, Hunsmann G, Pauli G: Detection of rarte cases of HTLV-I and -II infections and high numbers of HTLV-seroindeterminate results in Bavarian blood donors. Infusionsther Transfusionsmed 1999;26:328-334.

35 Hitzler W, Kiefhaber K, Runkel S, Jochum C: Prävalenz des humanen T-Zelleukämie-Virus I/II (HTLV-I/-II) bei Dauerblutspendern aus urbanen und ländlichen Gebieten. Infusionsther Transfusionsmed 1996;23:211-215. 